\title{
Pengaruh Model Pembelajaran Group Investigation Berbasis Tri Hita Karana Terhadap Kompetensi Pengetahuan IPA
}

\author{
*Putu Dian Okta Widiartini' ${ }^{1}$, Made Putra ${ }^{2}$, Ida Bagus Surya Manuaba ${ }^{3}$ \\ ${ }_{123}$ Pendidikan Guru Sekolah Dasar, Fakultas Ilmu Pendidikan, Universitas Pendidikan Ganesha Singaraja, Indonesia
}

\author{
A R T I C L E I N F O \\ Article history: \\ Received 10 May 2019 \\ Received in revised form \\ 10 June 2019 \\ Accepted 15 July 2019 \\ Available online 29 August \\ 2019 \\ Kata Kunci: \\ group investigation, tri hita \\ karana.

\section{Keywords:} \\ group investigation, tri hita \\ karana.
}

\begin{abstract}
A B S T R A K
Berdasarkan hasil observasi, dimana kompetensi pengetahuan IPA yang dimiliki peserta didik masih rendah. Tujuan Penelitian ini untuk mengetahui pengaruh model pembelajaran Group Investigation berbasis Tri Hita Karana terhadap kompetensi pengetahuan IPA siswa kelas IV SD. Jenis penelitian ini merupakan eksperimen semu, dengan bentuk Non-ekuivalen control group design. Seluruh siswa kelas IV SD sebanyak 309 siswa dijadikan populasi penelitian. Sampel ditentukan dengan teknik random sampling. Sampel penelitian ini adalah kelas IV SD sebagai kelompok eksperimen dengan jumlah 35 siswa dan kelompok kontrol dengan jumlah 42 siswa. Data kompetensi pengetahuan IPA dikumpulkan dengan instrumen berupa tes objektif pilihan ganda Data kompetensi IPA dianalisis dengan uji-t. Hasil analisis menunjukkan terdapat perbedaan yang signifikan kompetensi pengetahuan IPA antara kelompok siswa yang dibelajarkan melalui model pembelajaran Group Investigation berbasis Tri Hita Karana dengan kelompok siswa yang dibelajarkan melalui pembelajaran
\end{abstract} konvensional pada siswa kelas IV SD. Dapat disimpulkan model pembelajaran Group Investigation berbasis Tri Hita Karana berpengaruh terhadap kompetensi pengetahuan IPA siswa kelas IV SD. Penelitian ini dapat dijadikan alternatif dalam proses pembelajaran untuk membantu peserta didik meningkatkan kompetensi pengetahuan IPA dengan model pembelajaran Group Investigation berbasis Tri Hita Karana. 


\section{Pendahuluan}

Pendidikan merupakan wahana untuk meningkatkan dan mengembangkan kualitas sumber daya manusia. Selain itu, pendidikan adalah seperangkat proses berupa penanaman nilai, gagasan, konsep dan teori-teori yang bertujuan mengembangkan kepribadian, pengetahuan, keterampilan, dan tingkah laku serta mencapai cita-cita dan tujuan hidup (Mulyani, 2016). Salah satu masalah pokok dalam pembelajaran pada pendidikan formal (sekolah) ini adalah masih rendahnya daya serap peserta didik. Hal ini mendorong peserta didik untuk memiliki kemampuan yang membutuhkan pemikiran secara kritis, kreatif, logis, dan kemauan bekerja sama sehingga mampu menyelesaikan permasalahan yang dihadapi. Kegiatan belajar mengajar mengandung sejumlah komponen yang meliputi tujuan, bahan pelajaran, kegiatan belajar mengajar, metode, alat, dan sumber serta penilaian. Dari semua komponen tersebut metode mengajar merupakan salah satu komponen yang sangat penting dalam upaya pencapaian tujuan belajar. Karena pada hakikatnya proses belajar mengajar merupakan suatu upaya agar peserta didik mampu mengintegrasikan berbagai pengalaman sehingga dapat mencapai tujuan belajar yang diinginkan, dan diharapkan pula peserta didik mampu memahami materi yang disampaikan(Eva, 2016).

Pendidikan adalah "usaha sadar untuk menyiapkan peserta didik melalui kegiatan bimbingan, pengajaran, dan latihan baik yang dilaksanakan secara formal di sekolah maupun non-formal di luar sekolah" (Sagala, 2012 :Wardana, 2014). Sebagai makhluk pendidikan manusia memiliki berbagai potensi, seperti potensi akal, potensi hati, potensi jasmani, dan potensi ruhani (Wiyani, 2013:18). Dalam pendidikan ini akan berlangsung suatu proses antara guru dengan siswa untuk mencapai suatu tujuan pembelajaran. Berkaitan dengan hal tersebut, direncanakan sebuah pedoman dalam kegiatan pembelajaran yang disebut dengan kurikulum.

Undang-Undang Nomor 20 Tahun 2003 tentang Sistem Pendidikan Nasional dinyatakan bahwa kurikulum adalah seperangkat rencana dan pengaturan mengenai tujuan, isi, dan bahan pelajaran serta cara yang digunakan sebagai pedoman penyelenggaraan kegiatan pembelajaran untuk mencapai tujuan pendidikan tertentu. Kurikulum 2013 telah diterapkan pada Sekolah Dasar/Madrasah Ibtidaiyah sejak tahun pelajaran 2013/2014 (Kemendikbud, 2014). Kurikulum 2013 bertujuan untuk mempersiapkan manusia Indonesia agar memiliki kemampuan hidup sebagai pribadi dan warga negara yang beriman, produktif, kreatif, inovatif, dan afektif serta mampu berkontribusi pada kehidupan bermasyarakat, berbangsa, bernegara, dan peradapan dunia(Kemendikbud, 2014).

Proses pembelajaran pada kurikulum 2013 dilaksanakan dengan menggunakan pendekatan saintifik. Pendekatan saintifik merupakan suatu pendekatan pembelajaran yang mengutamakan temuan siswa sehingga siswa secara kreatif dan aktif membangun konsep, prinsip, melalui peristiwa mengamati, menanya, mengumpulkan informasi/ melakukan eksperimen, mengasosiasikan/mengolah informasi, dan mengkomunikasikan. Implementasi kurikulum 2013 diharapkan dapat meningkatkan kompetensi pengetahuan siswa salah satunya Ilmu Pengetahuan Alam (IPA). Menurut Susanto (2013:167) Ilmu Pengetahuan Alam (IPA) adalah usaha manusia dalam memahami alam semesta melalui pengamatan yang tepat pada sasaran, serta menggunakan prosedur, dan dijelaskan dengan penalaran sehingga mendapatkan suatu kesimpulan. Dengan adanya pembelajaran IPA siswa diharapkan dapat menguasai ilmu mengenai alam dan segala isinya termasuk bumi, manusia, hewan, dan tumbuhan serta dapat dapat menerapkannya dalam kehidupan sehari-hari. Dalam proses pembelajaran IPA di sekolah dasar juga perlu memperhatikan karakteristik siswa yang senang bermain, senang bekerja dalam kelompok, dan senang merasakan atau melakukan sesuatu secara langsung, sehingga tujuan pembelajaran yang tercapai sesuai harapan karena pembelajaran IPA sangat penting dan harus dikuasai dengan baik oleh siswa.

Pembelajaran IPA di sekolah dasar merupakan mata pelajaran yang sulit dipahami oleh sebagian siswa, siswa lebih senang mengobrol pada saat jam pelajaran, kurangnya menerapkan model-model pembelajaran yang inovatif lainnya dan kurang memanfaatkan keadaan sekitar untuk kegiatan pembelajaran, sehingga siswa menjadi kurang tertarik mempelajarinya. Berdasarkan observasi dan wawancara yang dilakukan pada hari kamis tanggal 11 bulan januari tahun 2018 pada siswa kelas IV di SD Gugus Pattimura Kecamatan Denpasar Selatan Tahun Ajaran 2018 dilihat dari nilai raport semester I yaitu, terbukti dari 309 siswa yang memperoleh nilai A sebanyak 16 siswa, yang memperoleh nilai B sebanyak 100 siswa, yang memperoleh nilai C sebanyak 193 siswa, dan yang memperoleh nilai D sebanyak 0 siswa. Pencapaian nilai yang diharapkan dalam kurikulum 2013 untuk kompetensi pengetahuan IPA mencapai nilai B. Berdasarkan data yang diperoleh, 116 siswa atau 37,54 \% yang sudah mencapain nilai yang diharapkan. Sedangkan, 193 siswa atau 63,48 \% yang belum menunjukan hasil belajar yang baik atau memperoleh predikat B. Sehingga terdapat kesenjangan antara harapan dan kenyataan dengan demikian, dipandang perlu ada peningkatan kompetensi pengetahuan IPA siswa (Sumber: Informasi dari masing-masing wali kelas IV di SD Gugus Pattimura Denpasar Selatan). Hal ini disebabkan oleh kurangnya penerapan model-model pembelajaran yang kurang inovatif dan 
memanfaatkan keadaan sekitar untuk proses pembelajaran. Pelaksanaan pembelajaran di kelas sebaiknya perlu didesain secara kreatif dan inovatif dengan memperhatikan karakteristik perkembangan siswa kelas IV SD. Dalam penelitian ini model pembelajaran yang dapat diterapkan adalah Model Group Investigation (GI) berbasis Tri Hita Karana.

Model pembelajaran kooperatif tipe Group Investigation (GI) merupakan model pembelajaran yang mendukung terjadinya dialog antara siswa satu dengan siswa lain yang akan mengacu pada aspeksosial afektif (Christina, 2016). Group Investigation (GI) adalah suatu model pembelajaran yang lebih menekankan pada pilihan dan kontrol siswa daripada menerapkan teknik-teknik pengajaran di ruang kelas. Selain itu juga memadukan prinsip belajar demokratis di mana siswa terlibat secara aktif dalam kegiatan pembelajaran, baik dari tahap awal sampai akhir pembelajaran termasuk di dalamnya siswa mempunyai kebebasan untuk memilih materi yang akan dipelajari sesuai dengan topik yang sedang dibahas (Shoimin, 2014:80). Menurut Burns (dalam Taniredja, 2012:74) secara umum perencanaan pengorganisasian kelas dengan menggunakan teknik kooperatif Group Investigation (GI) adalah kelompok dibentuk oleh siswa itu sendiri dengan beranggotakan 2-6 orang, tiap kelompok bebas memilih subtopik dari keseluruhan unit materi (pokok bahasan) yang akan diajarkan, dan kemudian membuat atau menghasilkan laporan kelompok, selanjutnya setiap kelompok mempresentasikan atau memamerkan laporannya kepada seluruh kelas, untuk berbagi dan saling tukar informasi temuan mereka. Agar proses pembelajaran yang dilaksanakan berjalan dengan maksimal, maka perlu dipadukan dengan Tri Hita Karana. Salah satu dari kearifan lokal yang ada di Bali adalah Tri Hita Karana. Tri Hita Karana adalah tiga hal pokok yang menyebabkan kesejahteraan dan kemakmuran hidup manusia (Wirawan, 2011:2).

Dalam Tri Hita Karana mencakup hubungan keseimbangan yang harmonis antara manusia dan Tuhan (Parahyangan), hubungan keseimbangan yang harmonis antara sesama manusia (Pawongan), dan yang terakhir hubungan keseimbangan yang harmonis antara manusia dengan alam (Palemahan) (Astami, 2016: Rai, 2019).

Pembelajaran kooperatif (Cooperative Learning) merupakan salah satu bentuk model pembelajaran sosial yang didasarkan pada teori belajar konstruktivisme (Hartoto, 2016). Model pembelajaran Group Investigation (GI) berbasis Tri Hita Karana merupakan model pembelajaran menggunakan sistem berkelompok saling bekerjasama menjalin hubungan harmonis dengan Tuhan, sesama manusia, dan dengan lingkungannya, sehingga semua anggota kelompok berhasil mencapai tujuan pembelajaran.

Berdasarkan uraian tersebut, secara teoretis Model Pembelajaran Group Investigation (GI) berbasis Tri Hita Karana berpengaruh terhadap kompetensi pengetahuan IPA, secara empiris perlu dibuktikan melalui penelitian yang berjudul "Pengaruh Model Pembelajaran Group Investigation Berbasis Tri Hita Karana Terhadap Kompetensi Pengetahuan IPA Siswa Kelas IV SD Gugus Pattimura Denpasar Selatan Tahun 2017/2018".

\section{Metode}

Penelitian ini dilaksanakan pada semester 2 Tahun Ajaran 2018 di kelas IV SD Gugus Pattimura Denpasar Selatan. Jenis penelitian ini adalah penelitian kuantitatif dengan desain eksperimental yaitu desain eksperimen semu (quasi eksperiment design). Bentuk desain eksperimen semu yang digunakan adalah non-equivalent control group design. Dalam desain ini terdapat dua kelompok sampel yang terdiri dari kelompok eksperimen dan kelompok kontrol sebagai subjek penelitian yang akan dibandingkan. Rancangan ini menggunakan pre test sebagai penyetaraan kelompok.

Secara skematis, desain eksperimen semu (quasy experimental design) yang digunakan pada penelitian ini dapat diilustrasikan sebagai berikut.

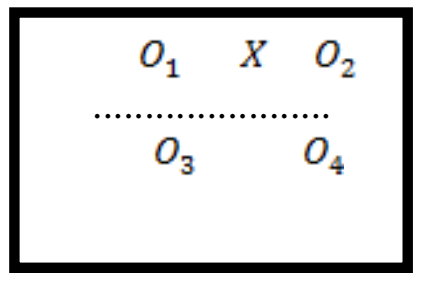

(Sumber: Sugiyono, 2017:79)

Gambar Non-Equivalent Control Group Design 


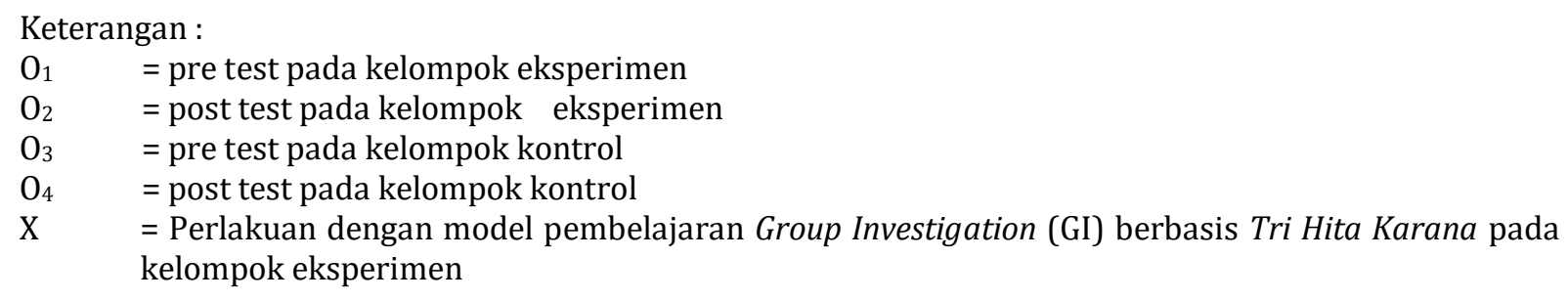

Teknik yang digunakan dalam penyetaraan kelompok adalah dengan menggunakan uji t. Setelah itu diberikan perlakuan, yaitu dengan memberikan model pembelajaran Group Investigation (GI) berbasis Tri Hita Karana kepada kelompok eksperimen dan memberikan pembelajaran konvensional kepada kelompok kontrol. Kemudian setelah diberikan perlakuan, dilakukan post test untuk mengetahui kompetensi pengetahuan IPA.

Populasi penelitian ini adalah seluruh siswa kelas IV SD Gugus Pattimura Kecamatan Denpasar Selatan Tahun Ajaran 2018, yang terdiri dari 8 kelas dalam 5 sekolah dasar, yang berjumlah 309 siswa. Setelah mengetahui populasi langkah selanjutnya adalah menentukan sampel penelitian. Teknik pengambilan sampel pada penelitian ini adalah Random Sampling sehingga setiap kelas mendapatkan peluang yang sama untuk menjadi sampel penelitian. Pemilihan sampel penelitian ini tidak dilakukan pengacakan individu melainkan hanya pengacakan kelas. Untuk menentukan sampel dalam penelitian ini, cara yang digunakan adalah dengan cara pengundian.

Hasil pengundian tersebut diperoleh 2 kelas yang dijadikan sampel penelitian yaitu kelas IVA SD Negeri 7 Sesetan dan kelas IV SD 18 Sesetan. Setelah itu, dua kelas hasil pengundian diberikan pre test, kemudian nilai atau skor dari hasil pre test yang dilakukan tersebut digunakan untuk penyetaraan kelas sampel. Untuk penyetaraan kelas sampel, nilai atau skor dari hasil pre-test seluruh populasi dianalisis menggunakan uji-t. Sebelum uji kesetaraan menggunakan uji-t, maka data hasil pre test diuji prasyarat yaitu normalitas sebaran data dan homogenitas varians. Setelah terdapat kelas yang diketahui setara secara akademik, maka dilakukan pengundian untuk menentukan kelas eksperimen dan kelas kontrol. Setelah dilakukan pengundian, kelas yang terpilih untuk menjadi kelas eksperimen adalah kelas IVA di SD Negeri 7 Sesetan dan untuk kelas kontrol terpilih kelas IV di SD Negeri 18 Sesetan.

Data yang dikumpulkan dalam penelitian ini adalah data kompetensi pengetahuan IPA siswa kelas IV di SD Gugus Pattimura Kecamata Denpasar Selatan pelajaran 2017/2018. Metode pengumpulan data merupakan cara atau teknik yang dilakukan untuk mengumpulkan data penelitian. Metode pengumpulan data yang digunakan dalam penelitian ini adalah dengan metode tes.

Pada penelitian ini data yang dianalisis adalah data mengenai kompetensi pengetahuan IPA siswa sehingga untuk memperoleh data tersebut penelitian ini menggunakan instrumen bentuk tes. Tes yang akan digunakan untuk mengukur kompetensi pengetahuan IPA siswa kelas IV berupa tes objektif dalam bentuk pilihan ganda biasa.

Tes objektif pilihan ganda biasa yang digunakan dalam penelitian ini terdiri dari 40 butir soal. Dalam tes ini dilakukan pengujian instrumen yaitu uji validitas, daya beda dan indeks kesukaran, dan reliabilitas.

Validitas yang digunakan dalam penelitian ini yaitu validitas isi dan validitas butir. Uji validitas isi dalam penelitian ini adalah menyusun instrumen berdasarkan kisi-kisi yang merujuk pada kurikulum. Dengan demikian, pengujian validitas isi instrumen penelitian ini juga dilakukan dengan melibatkan pendapat pakar/ahli. Untuk itu, dalam penyusunan tes penguasaan kompetensi pengetahuan IPA dilakukan konsultasi dengan dosen pada mata kuliah IPA dan guru kelas.

Untuk mengukur validitas butir tes kompetensi pengetahuan IPA dalam bentuk objektif pilihan ganda digunakan rumus koofesien korelasi point biserial (rpbi) karena tes yang digunakan bersifat dikotomi. Nilai yang diperoleh kemudian dibandingkan dengan nilai yang diperoleh dari rtabel, dengan taraf signifikansi sebesar 5\%, jika rhitung > rtabel, berarti instrumen dinyatakan valid dan jika rhitung $\leq$ $r_{\text {tabel, }}$ berarti instrumen dinyatakan tidak valid. Dari hasil perhitungan dengan $r_{\text {tabel }}$ pada taraf signifikansi 0,05 yaitu 0,316 terdapat 14 soal yang kurang dari $r_{\text {tabel }}(0,316)$ dan 26 butir soal yang lebih dari $r_{\text {tabel }}$ $(0,316)$. Soal yang dinyatakan valid kemudian dilanjutkan diuji dengan uji daya beda.

Untuk menentukan kelompok atas dan kelompok bawah adalah dengan mengambil masing-masing $27 \%$ dari jumlah sampel untuk kelompok atas dan kelompok bawah. Indeks daya beda yang digunakan untuk tes dalam penelitian ini adalah dari 0,4 sampai 1,00 dalam kategori cukup, baik dan baik sekali. Berdasarkan hasil pengujian, soal yang memiliki daya pembeda cukup yaitu sebanyak 5 butir soal, soal yang memiliki daya pembeda baik yaitu sebanyak 18 butir soal dan baik sekali sebanyak 3 butir soal dari 26 soal yang valid. 
Soal yang baik adalah soal yang tidak terlalu mudah atau tidak terlalu sukar. Soal yang telah diuji validitas butir tes dan uji daya beda kemudian diuji indeks kesukaran butir tes. Hasil uji tingkat kesukaran butir tes menunjukkan bahwa soal sukar sebanyak 5 butir, soal sedang sebanyak 15 butir, dan soal mudah sebanyak 6 soal dari 26 soal. Sedangkan indeks kesukaran tes, maka diketahui indeks kesukaran perangkat tes adalah 0,61 sehingga indeks kesukaran perangkat tes termasuk dalam kriteria sedang.

Uji reliabilitas dilakukan hanya pada butir soal yang telah diuji validitas butir tes dan dinyatakan valid. Tes dalam penelitian ini bersifat dikotomi sehingga rumus yang digunakan untuk uji reliabilitas tes adalah rumus Kuder Richardson (K-R. 20). Berdasarkan hasil perhitungan terhadap 26 butir tes yang dinyatakan valid dan memiliki daya beda cukup sampai dengan baik sekali, maka diperoleh r11=0,88. Berdasarkan hal tersebut, maka r11>0,70 yang berarti tes objektif tipe pilihan ganda biasa pada penelitian ini tergolong reliabel.

Metode analisis data dalam penelitian ini meliputi analisis statistik deskriptif dan analisis statistik inferensial. Teknik analisis statistik deskriptif dalam penelitian ini digunakan untuk mendeskripsikan penguasaan kompetensi pengetahuan IPA siswa yang dibelajarkan menggunakan model pembelajarn Group Investigation (GI) berbasis Tri Hita Karana dan penguasaan kompetensi pengetahuan IPA siswa yang dibelajarkan dengan pembelajaran konvensional. Adapun data yang akan disajikan dalam statistik deskriptif adalah perhitungan mean, standar deviasi dan varians.

Teknik analisis data yang dilakukan adalah uji hipotesis menggunakan uji t, sebelum dilakukan uji hipotesis, terlebih dahulu dilakukan uji prasyarat analisis yang meliputi uji normalitas sebaran data dan homogenitas varians. Uji Normalitas dimaksudkan untuk mengetahui apakah sebaran data skor kompetensi pengetahuan IPA siswa masing-masing kelompok berdistribusi normal atau tidak sehingga dapat menentukan teknik analisis datanya. Uji Normalitas sebaran data dalam penelitian ini menggunakan Chi-kuadrat $\left(\mathrm{X}^{2}\right)$. Hasil $X^{2}$ setelah perhitungan kemudian dibandingkan dengan $X^{2}$ tabel sesuai dengan taraf signifikasi yang telah ditetapkan. Jika $X^{2}$ hitung $<X^{2}$ tabel, maka tidak terdapat perbedaan antara $f_{o}$ dan $f_{e}$, sehingga $\mathrm{H}_{0}$ diterima yang berarti data berdistribusi normal. Jika $X^{2}$ hitung $\geq X^{2}$ tabel, maka terdapat perbedaan antara $f_{o}$ dan $f_{e}$ dan $\mathrm{H}_{\mathrm{o}}$ ditolak. Taraf signifikasi yang digunakan adalah $5 \%$ dan derajat kebebasannya $(\mathrm{dk})=(\mathrm{k}-1)$.

Uji Homogenitas dilakukan untuk menunjukkan bahwa perbedaan yang terjadi pada uji hipotesis benar-benar terjadi akibat adanya perbedaan varians antar kelompok, bukan sebagai akibat perbedaan dalam kelompok. Uji homogenitas dapat dilakukan apabila kelompok data tersebut berdistribusi normal. Uji homogenitas varians dilakukan dengan uji F. Pengujian dilakukan pada taraf signifikansi $5 \%$ dengan derajat kebebasan untuk pembilang $\mathrm{n}_{1}-1$ dan derajat kebebasan untuk penyebut $\mathrm{n}_{2}-1$, jika $F_{\text {hitung }} \leq F_{\text {tabel }}$ maka sampel homogen.

Data hasil penelitian yang telah diuji normalitas dan diuji homogenitas selanjutnya dilakukan uji hipotesis. Adapun hipotesis penelitian yang diuji yaitu $\mathrm{H}_{0}$ yang berbunyi tidak terdapat perbedaan yang signifikan kompetensi pengetahuan IPA antara kelompok siswa yang dibelajarkan melalui model pembelajaran Group Investigation (GI) berbasis Tri Hita Karana dengan kelompok siswa yang dibelajarkan melalui pembelajaran konvensional pada siswa kelas IV SD Gugus Pattimura Kecamatan Selatan Tahun Ajaran 2018. Analisis yang digunakan untuk menguji hipotesis penelitian ini adalah uji beda rerata (uji-t). Uji Hipotesis menggunakan uji-t dengan rumus polled varians. Dengan kriteria pengujian pada taraf signifikan $5 \%$ dengan $d k=n_{1}+n_{2}-2$, jika harga $t_{\text {hitung }} \leq t_{\text {tabel, }}$ maka $\mathrm{H}_{0}$ diterima, dan jika harga $t_{\text {hitung }}>t_{\text {tabel }}$ maka $\mathrm{H}_{0}$ ditolak. Berikut rumus uji-t yang digunakan

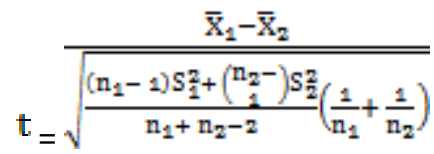

(Sugiyono, 2015:197)

Keterangan:

$\begin{array}{ll}\mathrm{S}_{1}{ }^{2} & =\text { varians kelompok eksperimen } \\ \mathrm{S}_{2}{ }^{2} & =\text { varians kelompok kontrol } \\ \overline{\mathrm{X}}_{1} & =\text { rerata nilai post test } \text { kelas eksperimen } \\ \overline{\mathrm{X}}_{2} & =\text { rerata nilai post test } \\ \mathrm{n}_{1} & =\text { jumlah kon siswa kelas eksperimen } \\ \mathrm{n}_{2} & =\text { jumlah siswa kelas kontrol }\end{array}$




\section{Hasil dan Pembahasan}

Pada Hasil analisis data dari kelompok eksperimen yang dibelajarkan dengan model pembelajaran Group Investigation (GI) berbasis Tri Hita Karana dan kelompok kontrol yang dibelajarkan dengan pembelajaran konvensional disajikan pada tabel 1.

Tabel 1. Deskripsi Kompetensi Pengetahuan IPA Kelompok Eksperimen dan Kelompok Kontrol

\begin{tabular}{lll}
\hline Statistik Deskriptif & Kelompok Eksperimen & Kelompok Kontrol \\
\hline N & 35 & 42 \\
Nilai Tertinggi & 92 & 85 \\
Nilai Terendah & 50 & 42 \\
Mean & 75,72 & 63,66 \\
Standar Deviasi & 10,35 & 9,49 \\
Varians & 107,24 & 90,03 \\
\hline
\end{tabular}

Data yang diperoleh kemudian dianalisis menggunakan stastistik inferensial yang terdiri dari uji prasyarat dan uji hipotesis. Uji prasyarat meliputi uji normalitas sebaran data dan uji homogenitas varians.

Hasil uji normalitas kelompok eksperimen. Diperoleh harga $X_{\text {hit }}^{2}$ yang diperoleh dari kelompok eksperimen yaitu 7,32. Harga tersebut kemudian dibandingkan dengan harga $X_{\text {tabel }}^{2}$ dengan derajat kebebasan $(\mathrm{dk})=\mathrm{k}-1=6-1=5$, maka diperoleh $X_{\text {tabel }}^{2}=11,07$. Berdasarkan perhitungan tersebut didapatkan $X_{\text {hit }}^{2}<X_{\text {tabel }}^{2}(7,32<11,07)$ maka $\mathrm{H}_{0}$ diterima, ini berarti sebaran data kompetensi pengetahuan IPA kelompok eksperimen berdistribusi normal.

Hasil uji normalitas kelompok kontrol. Diperoleh harga $X_{\text {hit }}^{2}$ yang diperoleh dari kelompok kontrol yaitu 2,44. Harga tersebut kemudian dibandingkan dengan harga $X_{\text {tabel }}^{2}$ dengan derajat kebebasan $(\mathrm{dk})=\mathrm{k}-1=6-1=5$, maka diperoleh $X_{\text {tabel }}^{2}=11,07$. Berdasarkan perhitungan tersebut didapatkan $X_{\text {hit }}^{2}<X_{\text {tabel }}^{2}(2,44<11,07)$ maka $H_{0}$ diterima, ini berarti sebaran data kompetensi pengetahuan IPA kelompok kontrol berdistribusi normal.

Uji homogenitas varian dilakukan dengan menggunakan uji-F. Hasil uji homogenitas, diperoleh $F_{\text {hitung }}=1,19$, harga ini kemudian dibandingkan dengan harga $\mathrm{F}_{\text {tabel }}$ dengan derajat kebebasan pembilang = $35-1=34$ dan derajat kebebasan penyebut $=42-1=41$ dengan taraf signifikasi 5\%, sehingga diperoleh $\mathrm{F}_{\text {tabel }}=1$,73. Karena harga $\mathrm{F}_{\text {hitung }}<\mathrm{F}_{\text {tabel }}(1,19<1,73)$. Ini berarti varian data kompetensi pengetahuan IPA antara kelompok eksperimen dan kelompok kontrol adalah homogen.

Data hasil penelitian yang telah diuji normalitas dan diuji homogenitas selanjutnya dilakukan uji hipotesis. Hipotesis penelitian yang diuji yaitu hipotesis nol $\left(\mathrm{H}_{0}\right)$. Hipotesis nol $\left(\mathrm{H}_{0}\right)$ yang diuji yaitu tidak terdapat pengaruh model pembelajaran Group Investigation (GI) berbasis Tri Hita Karana terhadap kompetensi pengetahuan IPA siswa kelas IV SD Gugus Pattimura Denpasar Selatan Tahun Ajaran 2018.

Kriteria dari pengujian yaitu $\mathrm{H}_{0}$ ditolak jika thitung $>$ ttabel, sedangkan $\mathrm{H}_{0}$ diterima jika thitung $\leq \mathrm{t}_{\text {tabel, }}$ dimana tabel didapatkan dari tabel distribusi t pada taraf signifikasi $5 \%$ dengan derajat kebebasan $\mathrm{dk}=$ $\left(n_{1}+n_{2}-2\right)$. Rekapitulasi hasil uji-t disajikan dalam tabel 2 .

Tabel 2. Rekapitulasi Hasil Analisis Uji Hipotesis Kelompok Eksperimen dan Kelompok Kontrol

\begin{tabular}{lcccccc}
\hline Kelompok & $\mathbf{N}$ & $\mathbf{d k}$ & $\overline{\boldsymbol{X}}$ & $\mathbf{S}^{\mathbf{2}}$ & thitung & $\mathbf{t}_{\text {tabel }}$ \\
\hline Eksperimen & 35 & \multirow{2}{*}{75} & 75,72 & 107,24 & \multirow{2}{*}{5,46} & 2,000 \\
Kontrol & 42 & & 63,66 & 90,03 & & \\
\hline
\end{tabular}

Hasil analisis uji $\mathrm{t}$ diperoleh $\mathrm{t}$ hitung $=5,46$. Harga tersebut kemudian dibandingkan dengan harga $\mathrm{t}$ tabel dengan $\mathrm{dk}=35+42-2=75$ dan taraf signifikansi $5 \%$ sehingga diperoleh harga $\mathrm{t}$ tabel $=2.00$, karena $t$ hitung $>t$ tabel maka Ho ditolak. Hal ini berarti terdapat perbedaan yang signifikan kompetensi pengetahuan IPA kelompok siswa yang dibelajarkan menggunakan model pembelajaran Group Investigation (GI) berbasis Tri Hita Karana dan kelompok siswa yang tidak dibelajarkan menggunakan model pembelajaran Group Investigation (GI) berbasis Tri Hita Karana pada siswa kelas IV SD Gugus Pattimura Denpasar Selatan Tahun Pelajaran 2017/2018. 
Berdasarkan hasil post-test yang telah diberikan kepada kedua kelompok sampel penelitian, diperoleh hasil perhitungan analisis data yang menunjukkan bahwa nilai rata-rata dari kelompok siswa yang mengikuti pembelajaran melalui model pembelajaran Group Investigation (GI) berbasis Tri Hita Karana memperoleh nilai rata-rata sebesar $\overline{\boldsymbol{X}}=75,72$, sedangkan kelompok siswa yang mengikuti pembelajaran konvensional memperoleh nilai rata-rata sebesar $\overline{\boldsymbol{X}}=63,66$ ).

Dari perolehan nilai kompetensi pengetahuan IPA pada kedua kelompok dapat diketahui bahwa kedua kelompok yang awalnya memiliki kemampuan setara, lalu setelah diberikan treatment yang berbeda perolehan nilai kompetensi pengetahuan IPA mengalami perbedaan. Kompetensi pengetahuan IPA siswa pada kelompok eksperimen lebih baik apabila dibandingkan dengan kompetensi pengetahuan IPA siswa pada kelompok kontrol.

Perbedaan yang signifikan kompetensi pengetahuan IPA kelompok eksperimen dan kelompok kontrol terjadi karena perbedaan pemberian treatment yang diberikan saat pembelajaran. Kelompok eksperimen diberikan pembelajaran dengan menerapkan model pembelajaran Group Investigation (GI) berbasis Tri Hita Karana memiliki nilai rata-rata yang lebih tinggi dibandingkan dengan kelompok kontrol yang tidak menerapkan model pembelajaran Group Investigation (GI) berbasis Tri Hita Karana.

Penerapan model pembelajaran Group Investigation (GI) berbasis Tri Hita Karana dapat meningkatkan faktor-faktor yang mempengaruhi kompetensi pengetahuan IPA. Siswa akan saling bekerjasama memecahkan masalah melalui hubungan keseimbangan yang harmonis dengan Tuhan, sesama manusia dan dengan lingkungan alam. Kegiatan ini akan membuat siswa merasa bersemangat dan senang mengikuti pembelajaran. Selain itu, interaksi siswa dapat juga ditingkatkan melalui berdiskusi dan berinteraksi dengan temannya dalam menemukan dan memahami suatu konsep. Selain itu, penerapan nilai-nilai Tri Hita Karana dapat mempermudahkan siswa dalam memahami suatu konsep IPA. Materi yang semula dianggap sulit akan terasa mudah untuk memahaminya jika menerapkan nilai-nilai Tri Hita Karana. Sehingga ketika pembelajaran berlangsung pada kelas eksperimen siswa terlihat bersemangat dan senang mengikuti pembelajaran. Interaksi meningkat karena pada model ini siswa diberikan kesempatan untuk berdiskusi dan berinteraksi dengan temannya dalam menemukan dan memahami suatu konsep. Setiap anggota kelompok juga bertanggungjawab atas segala sesuatu yang dikerjakan dalam kelompoknya, sehingga setiap siswa tidak ada yang diam. Siswa bertanggung jawab akan keberhasilan kelompoknya. Siswa saling bekerjasama dalam menyusun jawaban.

Shoimin (2014) mengungkapkan kelebihan Group Investigation (GI) berbasis Tri Hita Karana antara lain : a) Secara pribadi yaitu dalam proses belajarnya dapat bekerja secara bebas, memberi semangat untuk berinisiatif, kreatif, dan aktif, rasa percaya diri dapat lebih meningkat, dapat belajar untuk memecahkan dan menangani suatu masalah, mengembangkan antusiasme, b) Secara sosial yaitu meningkatkan belajar bekerja sama, belajar berkomunikasi baik dengan teman sendiri maupun guru, belajar berkomunikasi yang baik secara sistematis, belajar menghargai pendapat orang lain, meningkatkan partisipasi dalam membuat sesuatu, dan c) Secara akademis yaitu siswa terlatih untuk mempertanggungjawabkan jawaban yang diberikan, bekerja secara sistematis, mengembangkan dan melatih keterampilan fisik dalam berbagai bidang, merencanakan dan mengorganisasikan pekerjaannya, mengecek kebenaran jawaban yang mereka buat, selalu berfikir tentang cara atau strategi yang digunakan sehingga didapat suatu kesimpulan yang berlaku umum(Astami, 2016).

Penelitian ini didukung oleh penelitian yang relevan, yang dilakukan Kartiningsih (2016) menunjukan bahwa model pembelajaran Group Investigation memberi pengaruh yang signifikan terhadap kompetensi pengetahuan IPA pada siswa kelas IV di SD Gugus Moch. Hatta tahun pelajaran 2015/2016. Penelitian ini juga diperkuat oleh hasil penelitian dari Anjasari (2017) menunjukan bahwa model pembelajaran Talking Chips Berbasis Tri Hita Karana memberi pengaruh yang signifikan terhadap kompetensi pengetahuan IPS siswa kelas V SD Gugus IV Jendral Sudirman Kecamatan Denpasar Selatan tahun pelajaran 2016/2017.

\section{Simpulan dan Saran}

Berdasarkan hasil penelitian dan pembahasan dapat disimpulkan sebagai berikut. Berdasarkan hasil analisis statistik deskriptif kompetensi pengetahuan IPA kelompok eksperimen diperoleh $\overline{\boldsymbol{X}}=$ 75,72 dan rerata persentase kompetensi pengetahuan IPA kelompok eksperimen, M\% = 75,72\%. Rerata persentase kompetensi pengetahuan IPA tersebut kemudian dikonversikan pada tabel PAP skala lima, sehingga dapat diketahui kompetensi pengetahuan IPA siswa kelompok eksperimen berada pada kategori cukup. Berdasarkan hasil analisis statistik deskriptif kompetensi pengetahuan IPA kelompok kontrol diperoleh $\overline{\boldsymbol{X}}=63,66$ dan rerata persentase kompetensi pengetahuan IPA kelompok kontrol 63,66\%. Rerata persentase kompetensi pengetahuan IPA tersebut kemudian dikonversikan pada tabel PAP skala 
lima, sehingga dapat diketahui kompetensi pengetahuan IPA siswa kelompok kontrol berada pada kategori kurang. Terdapat pengaruh model pembelajaran Group Investigation (GI) berbasis Tri Hita Karana terhadap kompetensi pengetahuan IPA siswa kelas IV Gugus Pattimura Denpasar Selatan Tahun Pelajaran 2017/2018. Berdasarkan hasil uji normalitas dan homogenitas diketahui kompetensi pengetahuan IPA pada kelompok eksperimen dan kelompok kontrol berdistribusi normal dan memiliki varians yang homogen. Itu terbukti dari hasil analisis uji t diperoleh $t$ hitung $=5,46$. Harga tersebut kemudian dibandingkan dengan harga $t$ tabel dengan $d k=35+42-2=75$ dan taraf signifikansi $5 \%$ sehingga diperoleh harga $t$ tabel $=2,00$, karena $t$ hitung $>t$ tabel maka Ho ditolak. Rata-rata kompetensi pengetahuan IPA siswa kelompok eskperimen lebih dari rata-rata kompetensi pengetahuan IPA siswa kelompok kontrol $(\overline{\boldsymbol{X}}=75,72>\overline{\boldsymbol{X}}=63,66)$. Sehingga dapat disimpulkan bahwa model pembelajaran Group Investigation (GI) berbasis Tri Hita Karana berpengaruh terhadap kompetensi pengetahuan IPA siswa kelas IV SD Gugus Pattimura Denpasar Selatan Tahun Pelajaran 2017/2018.

Berdasarkan hasil penelitian ini, saran yang dapat disampaikan adalah sebagai berikut. 1) Kepada Guru : Guru hendaknya dapat menambah wawasannya mengenai inovasi pembelajaran sehingga mampu menerapkan ataupun mengembangkan pembelajaran di kelas secara lebih inovatif dan bervariasi agar dapat memberikan dampak positif dalam meningkatkan kompetensi pengetahuan siswa. Salah satu model pembelajaran yang dapat diterapkanoleh guru adalah model pembelajaran Group Investigation (GI) berbasis Tri Hita Karana. 2) Kepada Sekolah : Sekolah hendaknya menyediakan sarana yang maksimal untuk menunjang pembelajaran agar siswa semakin termotivasi untuk belajar dan memanfaatkan sarana tersebut untuk mengoptimalkan kompetensi siswa sehingga mutu sekolah menjadi semakin meningkat.. 3) Kepada Peneliti Lain :Dengan dilakukannya penelitian ini, diharapkan peneliti lain melakukan penelitian lebih lanjut pada materi pembelajaran yang berbeda atau dapat pula dilakukan penelitian lebih lanjut dengan menggunakan model pembelajaran Group Investigation (GI) berbasis Tri Hita Karana pada sumber data/sampel yang berbeda khususnya pada muatan pembelajaran IPA sehingga hasil penelitian benar-benar dapat menggambarkan keadaan sesungguhnya yang terjadi di lapangan.

\section{Daftar Rujukan}

Anjasari, Y. (2017). Pengaruh Model Pembelajaran Talking ChipsBerbasis Tri Hita Karana Terhadap Kompetensi Pengetahuan IPS. E-Journal PGSD Pendidikan Ganesha Mimbar PGSD, 5(2).

Astami, W. (2016). Penerapan Inkuiri Terbimbing Berbasis Tri Hita Karana Dapat Meningkatkan Sikap Sosial dan Kompetensi Pengetahuan IPS. E-Journal PGSD Pendidikan Ganesha Mimbar PGSD, 4(1).

Christina, L. V. (2016). Efektivitas Model Pembelajaran Tipe Group Investigation (GI) Dan Cooperative Integrated Reading And Composition (CIRC) Dalam Meningkatkan Kreativitas Berpikir Kritis dan Hasil Belajar IPS Siswa Kelas 4. Scolaria, 6(3), 217-230.

Eva, M. (2016). Pengaruh penggunaan model pembelajaran kooperatif tipe student facilitator and explaining terhadap pemahaman matematik peserta didik. Jurnal Penelitian Pendidikan Dan Pengajaran Matematika, 2(1), 29-34.

Hartoto, T. (2016). Model Pembelajaran Kooperatif Tipe Group Investigation (GI) Meningkatkan Aktivitas Dan Hasil Belajar Sejarah. Jurnal Historia, 4(2).

Kartiningsih, A. (2016). Pengaruh Model Pembelajaran Group Investigation Berbasis Pendekatan Saintifik Terhadap Penguasaan Kompetensi Pengetahuan Ipa Siswa Kelas IV SD Gugus Moch.Hatta Tahun Pelajaran 2015/2016. E-Journal PGSD Pendidikan Ganesha Mimbar PGSD, 4(1).

Kemendikbud. (2014). Permendikbud Nomor 57 Tahun 2014. Jakarta: Kementrian Pendidikan dan Kebudayaan.

Mulyani, E. (2016). Pengaruh Penggunaan Model Pembelajaran Kooperatif Tipe Student Facilitator and Explaining Terhadap Pemahaman Matematik Peserta Didik. Jurnal Penelitian Pendidikan Dan Pengajaran Matematika, 2(1).

Rai, I. B. \& S. (2019). Konsepsi Asta Brata Dalam Kepemimpinan Berlandaskan Tri Hita Karana. Jurnal Kajian Pendidikan Widya Accarya.

Sagala, S. (2012). Konsep dan Makna Pembelajaran. Bandung: Alfabeta.

Shoimin, A. (2014). Model Pembelajaran Inovatif dalam Kurikulum 2013. Yogyakarta: Ar-Ruzz Media.

Sugiyono. (2015). Metode Penelitian Pendidikan (Pendekatan Kuantitatif, kualitatif, dan R\&D). Bandung: 
Alfabeta.

Sugiyono. (2017). Metode Penelitian Kuantitatif, Kualitatif, dan R\&D. Bandung: Alfabeta.

Susanto, A. (2013). Teori Belajar \& Pembelajaran di Sekolah Dasar. Jakarta: KENCANA.

Taniredja, T. (2012). Model-model Pembelajaran Inovatif. Bandung: Alfabeta.

Wardana, I. K. N. (2014). Pengaruh Model Pembelajaran Role Playing Terhadap Keterampilan Berbicara Bahasa Indonesia Siswa Kelas V SD GUGUS II Kecamatan Karangasem. E-Journal Mimbar PGSD Universitas Pendidikan Ganesha, 2(1).

Wirawan, A. (2011). Tri Hita Karana. Surabaya: Paramita.

Wiyani, A. N. (2013). Manajemen Kelas. yogyakarta: Ar-Ruzz Media. 